\title{
Computed Tomography-Assessed Sarcopenia Indexes Predict Major Complications following Surgery for Hepatopancreatobiliary Malignancy: A Meta-Analysis
}

\author{
Qin Cao $^{a}$ Yan Xiong ${ }^{\mathrm{a}}$ Zibiao Zhong ${ }^{\mathrm{a}}$ Qifa Ye $^{\mathrm{a}, \mathrm{b}}$ \\ aWuhan University, Zhongnan Hospital of Wuhan University, Institute of Hepatobiliary Diseases of Wuhan \\ University, Transplant Center of Wuhan University, Hubei Key Laboratory of Medical Technology on Transplantation,

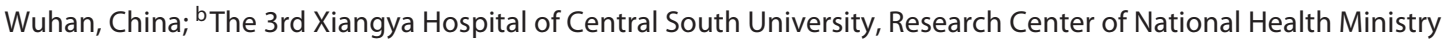 \\ on Transplantation Medicine Engineering and Technology, Changsha, China
}

\section{Keywords}

Sarcopenia $\cdot$ Computed tomography $\cdot$ Major complications . Surgery $\cdot$ Hepatopancreatobiliary

\begin{abstract}
Background: Computed tomography (CT)-assessed sarcopenia indexes have been reported to predict postoperative morbidity and mortality; however conclusions drawn from different indexes and studies remain controversial. Aim: The purpose of this meta-analysis was to evaluate various CTassessed sarcopenia indexes as predictors of risk for major complications in patients undergoing hepatopancreatobiliary surgery for malignancy. Methods: Medline/PubMed, Web of Science, and Embase databases were systematically searched to identify relevant studies published before June 2018. PRISMA guidelines for systematic reviews were followed. The pooled risk ratio (RR) for major postoperative complications (Clavien-Dindo $\geq$ III) was estimated in patients with sarcopenia versus patients without sarcopenia. Data extracted were meta-analyzed using Review Manager (version 5.3). Results: Twenty-eight studies comprising 6,656 patients were included in this study. CT-assessed sarcopenia indexes, such as skeletal muscle index (SMI, RR 1.36; 95\% Cl
\end{abstract}

$\left.1.14-1.63 ; p=0.0008 ; P^{2}=24 \%\right)$, psoas muscle index (PMI, RR $\left.1.35 ; 95 \% \mathrm{Cl} 1.15-1.58 ; p=0.0002 ; l^{2}=0 \%\right)$, muscle attenuation (MA, RR 1.40; 95\% Cl 1.14-1.73; $p=0.002 ; I^{2}=4 \%$ ), and intramuscular adipose tissue content (IMAC, RR $1.63 ; 95 \% \mathrm{Cl}$ $1.28-2.09 ; p<0.0001 ; I^{2}=0 \%$ ) were all predictors of postoperative major complications, although moderate heterogeneity existed and cutoffs for these indexes to define sarcopenia varied. Conclusions: All commonly used CT-assessed sarcopenia indexes, such as SMI, PMI, MA, and IMAC can predict the risk of major postoperative complications; however, a consensus on the cutoffs for these indexes to define sarcopenia is still lacking.

(c) 2018 S. Karger AG, Basel

\section{Introduction}

With the developments in surgical technique and concept of perioperative management, the morbidity and mortality after surgery have greatly improved [1-3]; however, postoperative complications have still been a major concern for clinicians, and preoperative risk assessment has remained of paramount significance in improving the outcomes of patients. As an index of function capacity,

\section{KARGER}

(c) 2018 S. Karger AG, Basel

E-Mail karger@karger.com

www.karger.com/anm 
the predictive value of sarcopenia in the occurrence of postoperative complications has been reported in a variety of studies [4-7].

The term "sarcopenia" was initially proposed by Rosenberg [8], and it described the loss of skeletal muscle mass in aged people. In 2010, the European Working Group [9] on Sarcopenia in Older People recommended that Sarcopenia be defined as a syndrome characterized by progressive and generalized loss of skeletal muscle mass and strength with a risk of adverse outcomes such as physical disability, poor quality of life and death in 2010. According to different etiologies, sarcopenia can be classified into the following 2 categories: primary sarcopenia caused by aging, and secondary sarcopenia, a pathological process, which is disease, activity or nutrition related.

Sarcopenia can be estimated and diagnosed by many validated techniques [10], which include dual X-ray absorptiometry, bio-electric impedance analysis, and computed tomography (CT) scanning. Considering the accessibility and simplicity, CT scanning is the most commonly used technique in clinical practice. A variety of studies have reported that CT-assessed sarcopenia indexes [11-14] can predict the risk of postoperative complications, especially major complications; however, conclusions drawn from different indexes and studies have remained controversial to some extent.

This meta-analysis aims to explore whether these commonly reported CT-assessed sarcopenia indexes can predict the risk of incidence of major postoperative complications following surgery for hepatopancreatobiliary malignancy.

\section{Methods}

\section{Literature Search}

A comprehensive literature search was performed according to PRISMA guidelines using Medline/PubMed, Web of Science, and Embase databases to identify studies on CT-assessed sarcopenia indexes in patients undergoing hepatopancreatobiliary surgery for malignancy before June 2018. The search query included ("sarcopenia" OR "muscle mass" OR "muscle depletion" OR "body composition") AND ("cancer" OR "neoplasm”) AND ("liver resection" OR "hepatectomy" OR "pancreatectomy" OR "pancreaticoduodenectomy" OR "bile duct"). In case of omission, the Google Scholar was also searched and the references lists of all primary studies were reviewed for relevant studies.

\section{Study Selection}

Two reviewers independently evaluated every retrieved study. The inclusion criteria were as follows: (1) patients undergoing surgery for hepatopancreatobiliary malignancy, (2) major postoperative complications were reported and graded according to the Cla-

CT-Assessed Sarcopenia Indexes Predict

Major Complications
vien-Dindo classification, and (3) patients were grouped according to the CT-assessed sarcopenia indexes. Exclusion criteria were as follows: (1) studies did not comprise outcome of interest, (2) full-text article was not available, (3) conference abstracts, (4) postoperative complications were not graded according to ClavienDindo classification, and (5) patients were grouped according to $\mathrm{CT}$-assessed indexes that were not related to sarcopenia. Furthermore, if 2 studies were performed at the same medical center, and the population sample was repeatedly reported, then, the study with a larger sample size was included.

\section{Data Extraction}

Two reviewers independently identified and extracted data from the original studies independently. When there was a discord between the 2 reviewers, a discussion was performed within the study team until an agreement was reached. The extracted data included the general characteristics of the study, the definition and cutoffs of CT-assessed sarcopenia indexes, the prevalence of sarcopenia, and the incidence of major postoperative complications (Clavien-Dindo [15] $\geq$ III).

\section{Quality Assessment}

The Newcastle-Ottawa assessment scale [16] was used to assess the quality of the included studies. In each study, the following 3 items were used to assess the quality of methodology: Selection, Comparability, and Outcome.

\section{Statistical Analysis}

Review Manager (Revman, version 5.3; The Cochrane Collaboration, The Nordic Cochrane Centre, Copenhagen, Denmark) was used to perform this meta-analysis. The value of $I^{2}$ was used to assess the heterogeneity among studies. $I^{2}$ values of 25,50 , and $75 \%$ were considered to correspond to low, moderate, and high levels of heterogeneity respectively. When the value of $I^{2}$ exceeded $50 \%$, the DerSimonian and Laird random effects model [17] was used to pool estimates; otherwise, the Mantel Haenszel fixed effects model [18] was applied. The outcomes were described as risk ratio (RR) and their associated $95 \% \mathrm{CI}$ and $p<0.05$ was considered statistically significant.

\section{Results}

\section{Study Selection}

A total of 836 references were identified from database searching, of which 58 articles were identified as relevant. From these 58 records, 30 were excluded (not graded by Clavien-Dindo classification, 3; no outcome of interest, 13; repeated report, 2; other treatments, 3; not grouped by sarcopenia indexes, 3 ; grouped according to indexes not related with sarcopenia, 4; postoperative muscle change, 2). Ultimately, 28 studies comprising 6,656 patients were included in this meta-analysis [11-14, 19-42] (as shown in Fig. 1).

\section{Study Characteristics}

The general characteristics of the included studies are presented in Table 1. Fifteen studies [11, 13, 20-23, 25, 27, 
Fig. 1. Study selection process.

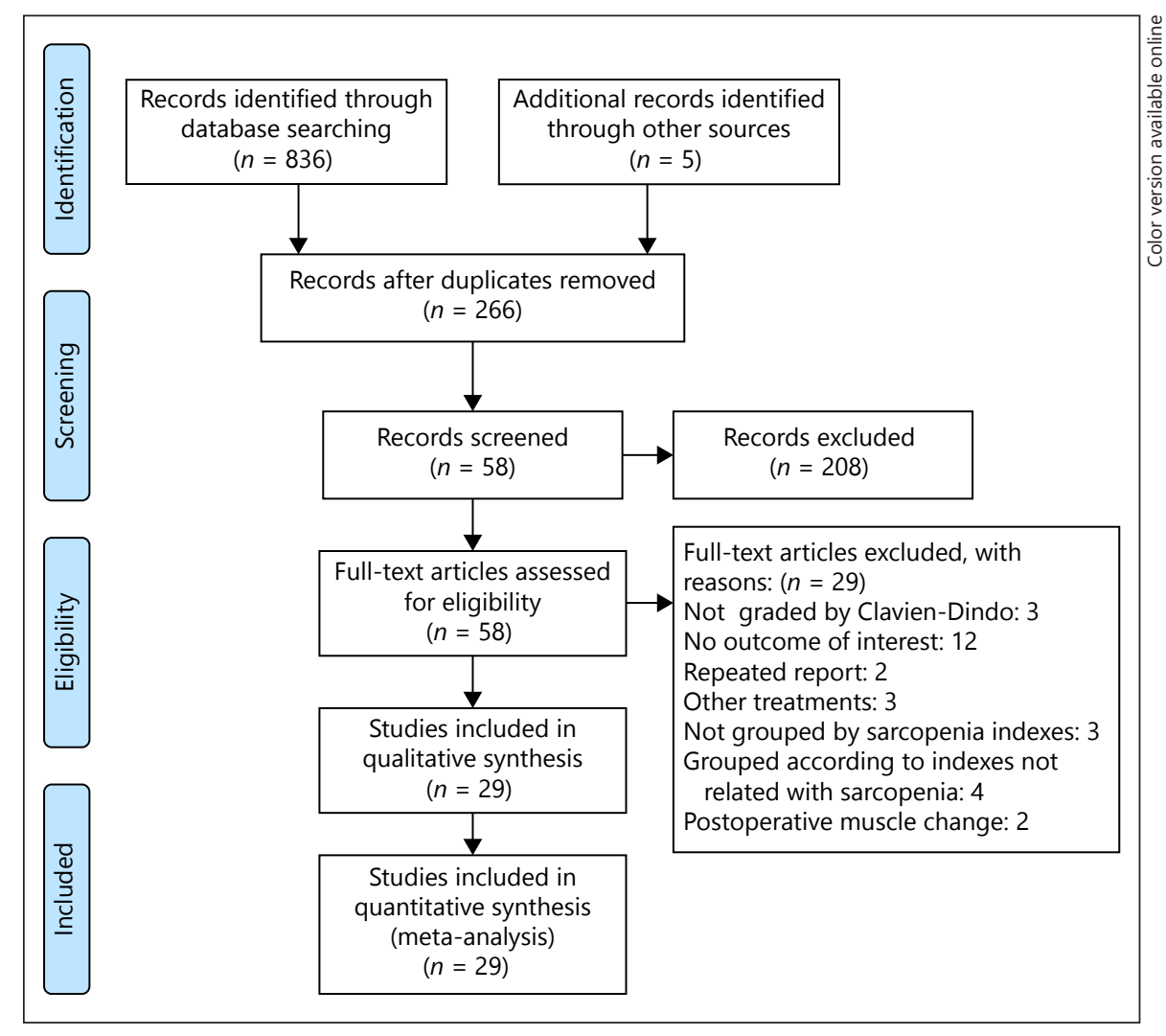

$31,33,34,36,39,40,42]$ were performed in Japan, with 4 in Netherlands [19, 28, 37, 41], 4 in America [12, 14, 29, 30], 1 in France [24], 1 in Canada [38], 1 in Austria [35], 1 in Korea [32], and 1 in China [26]. Among the included studies, 13 studies were directed at liver [11, 13, 19-29] malignancy, 2 bile duct [30, 31], 6 pancreas [12, 14, 32$35], 2$ periampullary $[36,37], 4$ periampullary and pancreas [38-41], and 1 hepatopancreatobiliary [42]. The sample size ranged from 67 to 763 . All of the studies were cohort studies and 26 studies were retrospective in nature [11-14, 19-40] and 2 studies were prospective [41, 42]. The quality score ranged from 5 to 7 .

Calculation Formula of CT-Assessed Sarcopenia Indexes

Based on the 28 included studies, 8 types of CT-assessed sarcopenia indexes were reported, which included skeletal muscle index/total abdominal muscle area (SMI/ TAMA), SMA/BSA index (SBI), psoas muscle index/total psaos muscle area(PMI/TPA), muscle attenuation/radiation attenuation (MA/RA), intramuscular adipose tissue content (IMAC), Hounsfield units average classification (HUAC), lean psoas muscle area (LPMA), and Total psoas muscle volume (TPV). The formula for calculating each index is showed in Table 2.

\section{Definition of Sarcopenia}

Based on the included 28 studies, sarcopenia was defined by using various indexes and cutoffs. The reported prevalence of sarcopenia ranged from 13.3 to $78 \%$. All of the image analysis was based on CT, and the third lumbar vertebra was the most commonly used level. SMI/ TAMA was the most commonly used index, and it was used in 16 studies [11, 13, 19, 21, 23-28, 32, 34, 36-39], with SBI in 2 studies [40, 42], PMI/TPA in 7 studies [12, $20,22,29-31,33]$, MA/RA in 5 studies $[13,24,37,38$, 41], IMAC in 4 studies [20,27, 31, 33], HUAC in 1 study [35], LPMA in 1 study [14], and TPV in 1 study [12] (Table 3).

\section{Cutoff for the Sarcopenia Index}

Predefined or study-specific cutoffs were used to define sarcopenia. Predefined cutoffs were adopted in 8 studies [11, 20, 24-28, 39], and optimum stratification, receiver operator characteristic curve and study-specific percentiles were used in the other studies [12-14, 21-23, $29-38,40-42]$. Sex-specific cutoffs were employed in almost all of the included studies, and on comparison with males, females showed a relatively lower muscle mass and MA (Table 3). 
Table 1. General characteristics of the studies included in this review

\begin{tabular}{|c|c|c|c|c|c|c|}
\hline Reference & Country & Study period & Study design & $\begin{array}{l}\text { No. of } \\
\text { patients }\end{array}$ & Disease type & $\begin{array}{l}\text { Quality } \\
\text { assessment } \\
\text { (NOS) }\end{array}$ \\
\hline Coelen et al. [19], 2015 & Netherlands & 1998-2013 & Retrospective & 100 & Liver & 7 \\
\hline Hamaguchi et al. [20], 2016 & Japan & 2005-2014 & Retrospective & 492 & Liver & 7 \\
\hline Higashi et al. [21], 2016 & Japan & $2007-2013$ & Retrospective & 144 & Liver & 6 \\
\hline Kobayashi et al. [11], 2017 & Japan & 2005-2015 & Retrospective & 465 & Liver & 6 \\
\hline Okumura et al. [13], 2017 & Japan & $2004-2015$ & Retrospective & 109 & Liver & 7 \\
\hline Coelen et al. [22], 2015 & Japan & $2008-2014$ & Retrospective & 256 & Liver & 5 \\
\hline Takagi et al. [23], 2016 & Japan & 2007-2013 & Retrospective & 254 & Liver & 6 \\
\hline Voron et al. [24], 2015 & France & 2006-2012 & Retrospective & 109 & Liver & 5 \\
\hline Yabusaki et al. [25], 2016 & Japan & 2003-2014 & Retrospective & 195 & Liver & 6 \\
\hline Zhou et al. [26], 2015 & China & 2000-2014 & Retrospective & 67 & Liver & 6 \\
\hline Kobayashi et al. [27], 2018 & Japan & 2005-2014 & Retrospective & 124 & CRLM & 6 \\
\hline Lodewick et al. [28], 2014 & Netherlands & $2005-2012$ & Retrospective & 171 & CRLM & 5 \\
\hline Peng et al. [29], 2011 & USA & 2000-2009 & Retrospective & 259 & CRLM & 6 \\
\hline Chakedis et al. [30], 2018 & USA & 2007-2016 & Retrospective & 78 & Bile duct & 6 \\
\hline Okumura et al. [31], 2016 & Japan & 2004-2013 & Retrospective & 207 & Bile duct & 6 \\
\hline Amini et al. [12], 2015 & USA & 1996-2014 & Retrospective & 763 & Pancreas & 6 \\
\hline Choi et al. [32], 2018 & Korea & 2008-2015 & Retrospective & 180 & Pancreas & 6 \\
\hline Okumura et al. [33], 2015 & Japan & 2004-2013 & Retrospective & 230 & Pancreas & 6 \\
\hline Okumura et al. [34], 2017 & Japan & 2004-2015 & Retrospective & 301 & Pancreas & 7 \\
\hline Onesti et al. [14], 2016 & USA & 2005-2012 & Retrospective & 260 & Pancreas & 7 \\
\hline Wagner et al. [35], 2018 & Austria & 2006-2015 & Retrospective & 424 & Pancreas & 5 \\
\hline Sui et al. [36], 2018 & Japan & 2005-2014 & Retrospective & 354 & Periampullary & 6 \\
\hline Van Rijssen et al. [37], 2017 & Netherlands & 2000-2012 & Retrospective & 166 & Periampullary & 7 \\
\hline Stretch et al. [38], 2018 & Canada & 2003-2011 & Retrospective & 123 & Periampullary/pancreas & 6 \\
\hline Nishida et al. [39], 2016 & Japan & 2010-2014 & Retrospective & 266 & Periampullary/pancreas & 5 \\
\hline Takagi et al. [40], 2017 & Japan & 2007-2013 & Retrospective & 219 & Periampullary/pancreas & 6 \\
\hline van Dijk et al. [41], 2017 & Netherlands & $2008-2013$ & Prospective & 186 & Periampullary/pancreas & 5 \\
\hline Takagi et al. [42], 2017 & Japan & $2013-2014$ & Prospective & 154 & HPB & 5 \\
\hline
\end{tabular}

CRLM, colorectal liver metastasis; HB, hepatobiliary surgery; HPB, hepatopancreatobiliary surgery.

\section{Main Effects: Major Postoperative Complications \\ SMI, TAMA, and SBI}

As both the SBI and SMI indexes both reflected the total skeletal muscle mass, one adjusted for height and the other for body surface area, and the data were pooled to- gether. As shown in Figure 2a, based on 18 studies [11, 13, $19,21,23-28,32,34,36-39,40,42]$ comprising 3,501 patients and 782 major complications, low preoperative SMI was associated with an increased risk of major complications (RR 1.36; 95\% CI 1.14-1.63; $p=0.0008 ; I^{2}=24 \%$ ). 
Table 2. Formulae for calculating CT-assessed sarcopenia indexes

\begin{tabular}{ll}
\hline SMI/TAMA & All skeletal muscle mass/height ${ }^{2}$ \\
\hline PMI/TPA & Total psaos muscle area/height ${ }^{2}$ \\
\hline TPV & Total psaos muscle volume/height ${ }^{2}$ \\
\hline SBI & All skeletal muscle mass/body surface area \\
\hline MA/RA & Mean CT value of the cross-sectional area of the skeletal muscle HU \\
\hline LPMA & LPMA = total psoas area $\times$ lean PMD; lean PMD $=($ mean psoas density +85$) / 170 ;$ PMD $=($ left mean + right mean $) / 2$ \\
\hline IMAC & CT attenuation of the multifidus muscles $(+$ erector spinae; HU $) / C T$ attenuation of subcutaneous adipose tissue $($ HU $)$ \\
\hline HUAC & $\begin{array}{l}\text { HUAC }=(\text { RHUC }+ \text { LHUC }) / 2 ; \text { RHUC }=(\text { right HU } \times \text { right psoas area }) /(\text { total psoas area }) ; \text { LHUC }=\text { left HU } \times \text { left psoas } \\
\text { area } / \text { total psoas area })\end{array}$ \\
\hline
\end{tabular}

PMI and TPA

As shown in Figure 2b, based on 7 studies [12, 20, 22, 29-31,33] comprising 2,285 patients and 479 major complications, low preoperative PMI was associated with an increased risk of major complications (RR 1.35; 95\% CI $\left.1.15-1.58 ; p=0.0002 ; I^{2}=0 \%\right)$.

\section{MA and RA}

As shown in Figure 2c, based on 5 studies [13, 24, 37, 38,41 ] comprising 885 patients and 221 major complications, preoperative incidence of sarcopenia, which was defined by MA/radiation attenuation on CT was associated with an increased risk of major complications ( $\mathrm{RR}$ $1.40 ; 95 \%$ CI $\left.1.14-1.73 ; p=0.002 ; I^{2}=4 \%\right)$.

Intramuscular Adipose Tissue Content

As shown in Figure 2d, based on 4 studies [20, 27, 31, 33] comprising 1,053 patients and 206 major complications, preoperative incidence of sarcopenia , which was defined by IMAC in CT was associated with an increased risk of major complications (RR 1.63; 95\% CI 1.28-2.09; $\left.p<0.0001 ; I^{2}=0 \%\right)$.

\section{HUAC, TPV, and LPMA}

Due to the scarcity of original studies reporting the HUAC [35], TPV [12], and LPMA [14] indexes, the data were not pooled. In the 3 included studies, both lower HUAC (HR 1.55, 95\% CI 0.98-2.45, $p=0.014$ ) and TPV (OR 1.69, 95\% CI 1.16-2.46, $p=0.006$ ) were both associated with an increased risk of major postoperative complications. Also, patients with lower LPMA also showed a higher incidence of major complications when compared to those with higher LPMA $(p<0.05)$.

\section{Discussion}

With the developments in surgical technique and concept of perioperative management, the postoperative incidences of morbidity and mortality have greatly decreased; however, the condition is still not satisfactory, and the incidence of major complications after hepatopancreatobiliary surgery is still high [48-50]. The prevention and treatment of major complications have remained of paramount significance in improving the outcomes of patients, and the preoperative risk evaluation and clinical intervention are effective measures to prevent the occurrence of major complications. The role of sarcopenia as an effective predictor of postoperative complications has been reported in many clinical studies [51-53]. In patients with end-stage liver disease and awaiting transplantation, a model including sarcopenia could even surpass the MELD score in predicting waiting list mortality [54]. A variety of studies [19,30,32] have also explored the role of sarcopenia in the occurrence of complications in patients undergoing hepatopancreatobiliary surgery. In these studies, sarcopenia was defined by various indexes; however, the conclusions drawn from different studies and various indexes have remained controversial. This meta-analysis aimed to evaluate whether these different CT-assessed sarcopenia indexes could predict the postoperative risk of major complications in patients undergoing hepatopancreatobiliary surgery for malignancy. It was noted that the outcome validated the role of CT-assessed sarcopenia indexes, such as SMI, PMI, MA, and IMAC as effective predictors, although the cutoffs for these indexes to define sarcopenia still varied.

Sarcopenia is a broad concept that comprises the following 3 aspects: contents of muscle mass, muscle
Cao/Xiong/Zhong/Ye 
Table 3. Definition of sarcopenia

\begin{tabular}{|c|c|c|c|c|c|}
\hline Reference & $\begin{array}{l}\text { Modality } \\
\text { and level }\end{array}$ & Index & Sex-specific cutoff values & $\begin{array}{l}\text { Prevalence of } \\
\text { sarcopenia, } n(\%)\end{array}$ & $\begin{array}{l}\text { Way to identify cutoff } \\
\text { values }\end{array}$ \\
\hline Coelen et al. [19], 2015 & $\mathrm{CT} / \mathrm{L} 3$ & SMI & Males: $46.8 \mathrm{~cm}^{2} / \mathrm{m}^{2}$; females: $39.1 \mathrm{~cm}^{2} / \mathrm{m}^{2}$ & $42(42)$ & Optimal stratification \\
\hline Hamaguchi et al. [20], 2016 & CT/umbilical & PMI, IMAC & $\begin{array}{l}\text { PMI: males: } 6.089 \mathrm{~cm}^{2} / \mathrm{m}^{2} \text {; females: } 4.020 \mathrm{~cm}^{2} / \mathrm{m}^{2} \\
\text { IMAC: males: } 0.324 \text {; females: }-0.138\end{array}$ & $\begin{array}{l}141(28.7) \\
219(44.5)\end{array}$ & $\begin{array}{l}\text { Adopt the standards of } \\
\text { Hamaguchi } 2015 \text { [43] }\end{array}$ \\
\hline Higashi et al. [21], 2016 & $\mathrm{CT} / \mathrm{L} 3$ & SMI & SMI: males: $43.2 \mathrm{~cm}^{2} / \mathrm{m}^{2}$; females: $35.3 \mathrm{~cm}^{2} / \mathrm{m}^{2}$ & $72(50)$ & Median \\
\hline Kobayashi et al. [11], 2017 & $\mathrm{CT} / \mathrm{L} 3$ & SMI & SMI: males: $40.31 \mathrm{~cm}^{2} / \mathrm{m}^{2}$; females: $30.88 \mathrm{~cm}^{2} / \mathrm{m}^{2}$ & $62(13.3)$ & $\begin{array}{l}\text { The data of } 657 \text { healthy } \\
\text { LDLT donors [44] }\end{array}$ \\
\hline Okumura et al. [13], 2017 & CT/L3 & SMI, MA & $\begin{array}{l}\text { SMI: males: } 52.5 \mathrm{~cm}^{2} / \mathrm{m}^{2} \text {; females: } 41.2 \mathrm{~cm}^{2} / \mathrm{m}^{2} \\
\text { MA: males: } 38.3 \text {; females: } 31.0\end{array}$ & $\begin{array}{l}69(63.3) \\
53(48.6)\end{array}$ & $\begin{array}{l}\text { Receiver operator } \\
\text { characteristic curve }\end{array}$ \\
\hline Coelen et al. [22], 2015 & CT/L3 & TPA & Males: $536 \mathrm{~mm}^{2} / \mathrm{m}^{2}$; females: $378 \mathrm{~mm}^{2} / \mathrm{m}^{2}$ & $85(33.2)$ & Lowest tertile \\
\hline Takagi et al. [23], 2016 & $\mathrm{CT} / \mathrm{L} 3$ & SMI & Males: $46.4 \mathrm{~cm}^{2} / \mathrm{m}^{2}$; females: $37.6 \mathrm{~cm}^{2} / \mathrm{m}^{2}$ & $118(46.5)$ & Optimum stratification \\
\hline Voron et al. [24], 2015 & $\mathrm{CT} / \mathrm{L} 3$ & SMI & Males: $52.4 \mathrm{~cm}^{2} / \mathrm{m}^{2}$; females: $38.9 \mathrm{~cm}^{2} / \mathrm{m}^{2}$ & $59(54.1)$ & $\begin{array}{l}\text { Adopt the standards of } \\
\text { Fearon } 2011 \text { [45] }\end{array}$ \\
\hline Yabusaki et al. [25], 2016 & CT/L3 & SMI & Males: $43.75 \mathrm{~cm}^{2} / \mathrm{m}^{2}$; females: $41.10 \mathrm{~cm}^{2} / \mathrm{m}^{2}$ & $89(45.6)$ & $\begin{array}{l}\text { Adopt the standards of } \\
\text { Vledder } 2012\left[46^{]}\right.\end{array}$ \\
\hline Zhou et al. [26], 2015 & $\mathrm{CT} / \mathrm{L} 3$ & SMI & Males: $43.75 \mathrm{~cm}^{2} / \mathrm{m}^{2}$; females: $41.10 \mathrm{~cm}^{2} / \mathrm{m}^{2}$ & $33(49.3)$ & $\begin{array}{l}\text { Adopt the standards of } \\
\text { Vledder } 2012 \text { [46] }\end{array}$ \\
\hline Kobayashi et al. [27], 2018 & $\mathrm{CT} / \mathrm{L} 3$ & SMI, IMAC & $\begin{array}{l}\text { SMI: males: } 40.31 \mathrm{~cm}^{2} / \mathrm{m}^{2} \text {; females: } 30.88 \mathrm{~cm}^{2} / \mathrm{m}^{2} \\
\text { IMAC: males: }-0.358 \text {; females: }-0.229\end{array}$ & $\begin{array}{l}24(19.4) \\
74(59.7)\end{array}$ & $\begin{array}{l}\text { The data of } 657 \text { healthy } \\
\text { LDLT donors [ } 44]\end{array}$ \\
\hline Lodewick et al. [28], 2014 & $\mathrm{CT} / \mathrm{L} 3$ & SMI & $\begin{array}{l}\text { Females: } 41 \mathrm{~cm}^{2} / \mathrm{m}^{2} \\
\text { Males: } 43 \mathrm{~cm}^{2} / \mathrm{m}^{2}(\mathrm{BMI}<25) ; 53 \mathrm{~cm}^{2} / \mathrm{m}^{2}(\mathrm{BMI}>25)\end{array}$ & $80(46.8)$ & $\begin{array}{l}\text { Adopt the standards of } \\
\text { Martin } 2013 \text { [47] }\end{array}$ \\
\hline Peng et al. [29], 2011 & $\mathrm{CT} / \mathrm{L} 3$ & TPA & TPA: $500 \mathrm{~mm}^{2} / \mathrm{m}^{2}$ & $41(15.8)$ & Optimum stratification \\
\hline Chakedis et al. [30], 2018 & $\mathrm{CT} / \mathrm{L} 3$ & PMI & $\begin{array}{l}\text { Males: } 7.32 \mathrm{~cm}^{2} / \mathrm{m}^{2} \text {; females: } 5.16 \mathrm{~cm}^{2} / \mathrm{m}^{2}(\mathrm{BMI}>30) \\
\text { Males: } 6.25 \mathrm{~cm}^{2} / \mathrm{m}^{2} \text {; females: } 4.21 \mathrm{~cm}^{2} / \mathrm{m}^{2}(\mathrm{BMI}<30)\end{array}$ & $30(38.5)$ & Optimum stratification \\
\hline Okumura et al. [31], 2016 & CT/L3 & PMI, IMAC & $\begin{array}{l}\text { PMI: males: } 6.15 \mathrm{~cm}^{2} / \mathrm{m}^{2} \text {; females: } 3.98 \mathrm{~cm}^{2} / \mathrm{m}^{2} \\
\text { IMAC: males: }-0.341 \text {; females: }-0.096\end{array}$ & $\begin{array}{l}71(34.3) \\
91(44.0)\end{array}$ & $\begin{array}{l}\text { Receiver operator } \\
\text { characteristic curve }\end{array}$ \\
\hline Amini et al. [12], 2015 & $\mathrm{CT} / \mathrm{L} 3$ & TPA, TPV & $\begin{array}{l}\text { TPA: males: } 564.2 \mathrm{~mm}^{2} / \mathrm{m}^{2} \text {; females: } 414.5 \mathrm{~mm}^{2} / \mathrm{m}^{2} \\
\text { TPV: males: } 17.2 \mathrm{~cm}^{3} / \mathrm{m}^{2} \text {; females: } 12.0 \mathrm{~cm}^{3} / \mathrm{m}^{2}\end{array}$ & $\begin{array}{l}192(25.2) \\
152(19.9)\end{array}$ & Optimum stratification \\
\hline Choi et al. [32], 2018 & $\mathrm{CT} / \mathrm{L} 3$ & SMI & Males: $45.3 \mathrm{~cm}^{2} / \mathrm{m}^{2}$; females: $39.3 \mathrm{~cm}^{2} / \mathrm{m}^{2}$ & $60(33.3)$ & Lowest tertile \\
\hline Okumura et al. [33], 2015 & $\mathrm{CT} / \mathrm{L} 3$ & PMI, IMAC & $\begin{array}{l}\text { PMI: males: } 5.896 \mathrm{~cm}^{2} / \mathrm{m}^{2} \text {; females: } 4.067 \mathrm{~cm}^{2} / \mathrm{m}^{2} \\
\text { IMAC: males: }-0.343 \text {; females: }-0.256\end{array}$ & $\begin{array}{r}64(27.8) \\
142(61.7)\end{array}$ & $\begin{array}{l}\text { Receiver operator } \\
\text { characteristic curve }\end{array}$ \\
\hline Okumura et al. [34], 2017 & CT/L3 & SMI, MA & $\begin{array}{l}\text { SMI: males: } 47.1 \mathrm{~cm}^{2} / \mathrm{m}^{2} \text {; females: } 36.6 \mathrm{~cm}^{2} / \mathrm{m}^{2} \\
\text { MA: males: } 35.1 \text {; females: } 30.7\end{array}$ & $\begin{array}{l}120(39.9) \\
144(47.8)\end{array}$ & $\begin{array}{l}\text { Receiver operator } \\
\text { characteristic curve }\end{array}$ \\
\hline Onesti et al. [14], 2016 & $\mathrm{CT} / \mathrm{L} 4$ & LPMA & LPMA: $601-1,412 \mathrm{~cm}^{2}$ & $86(33.1)$ & Lowest tertile \\
\hline Wagner et al. [35], 2018 & $\mathrm{CT} / \mathrm{L} 3$ & HUAC & Males: 16.29; females: 15.69 & $145(34.2)$ & Lowest quartile \\
\hline Sui et al. [36], 2018 & $\mathrm{CT} / \mathrm{L} 3$ & SMI & Males: $40.5 \mathrm{~cm}^{2} / \mathrm{m}^{2}$; females: $33.5 \mathrm{~cm}^{2} / \mathrm{m}^{2}$ & $87(24.6)$ & Lowest quartile \\
\hline Van Rijssen et al. [37], 2017 & CT/L3 & SMI, MAI & $\begin{array}{l}\text { SMI: males: } 53.5 \mathrm{~cm}^{2} / \mathrm{m}^{2} \text {; females: } 46.4 \mathrm{~cm}^{2} / \mathrm{m}^{2} \\
\text { MAI: males: } 36.3 \text {; females: } 36.0\end{array}$ & $\begin{array}{r}130(78) \\
81(48.8)\end{array}$ & Optimum stratification \\
\hline Stretch et al. [38], 2018 & $\mathrm{CT} / \mathrm{L} 3$ & SMI, MA & $\begin{array}{l}\text { Males: } 47.7 \mathrm{~cm}^{2} / \mathrm{m}^{2} \text {; females: } 36.5 \mathrm{~cm}^{2} / \mathrm{m}^{2} \\
\text { MA: } 30\end{array}$ & $\begin{array}{l}50(40.7) \\
31(25.2)\end{array}$ & $\begin{array}{l}\text { Lowest } 40 \text { th percentile } \\
\text { Lowest quartile }\end{array}$ \\
\hline Nishida et al. [39], 2016 & CT/L3 & SMI & $\begin{array}{l}\text { Females: } 41 \mathrm{~cm}^{2} / \mathrm{m}^{2} \\
\text { Males: } 43 \mathrm{~cm}^{2} / \mathrm{m}^{2}(\mathrm{BMI}<25) ; 53 \mathrm{~cm}^{2} / \mathrm{m}^{2}(\mathrm{BMI}>25)\end{array}$ & $132(49.6)$ & $\begin{array}{l}\text { Adopt the standards of } \\
\text { Martin } 2013 \text { [47] }\end{array}$ \\
\hline Takagi et al. [40], 2017 & $\mathrm{CT} / \mathrm{L} 3$ & SBI & Males: $68.5 \mathrm{~cm}^{2} / \mathrm{m}^{2}$; females: $52.5 \mathrm{~cm}^{2} / \mathrm{m}^{2}$ & $55(25.1)$ & Lowest quartile \\
\hline van Dijk et al. [41], 2017 & $\mathrm{CT} / \mathrm{L} 3$ & RA & MAI: males: 33.9; females: 30.9 & $62(33.3)$ & Lowest tertile \\
\hline Takagi et al. [42], 2017 & $\mathrm{CT} / \mathrm{L} 3$ & SBI & Males: $71.6 \mathrm{~cm}^{2} / \mathrm{m}^{2}$; females: $55.3 \mathrm{~cm}^{2} / \mathrm{m}^{2}$ & $38(24.7)$ & Lowest quartile \\
\hline
\end{tabular}




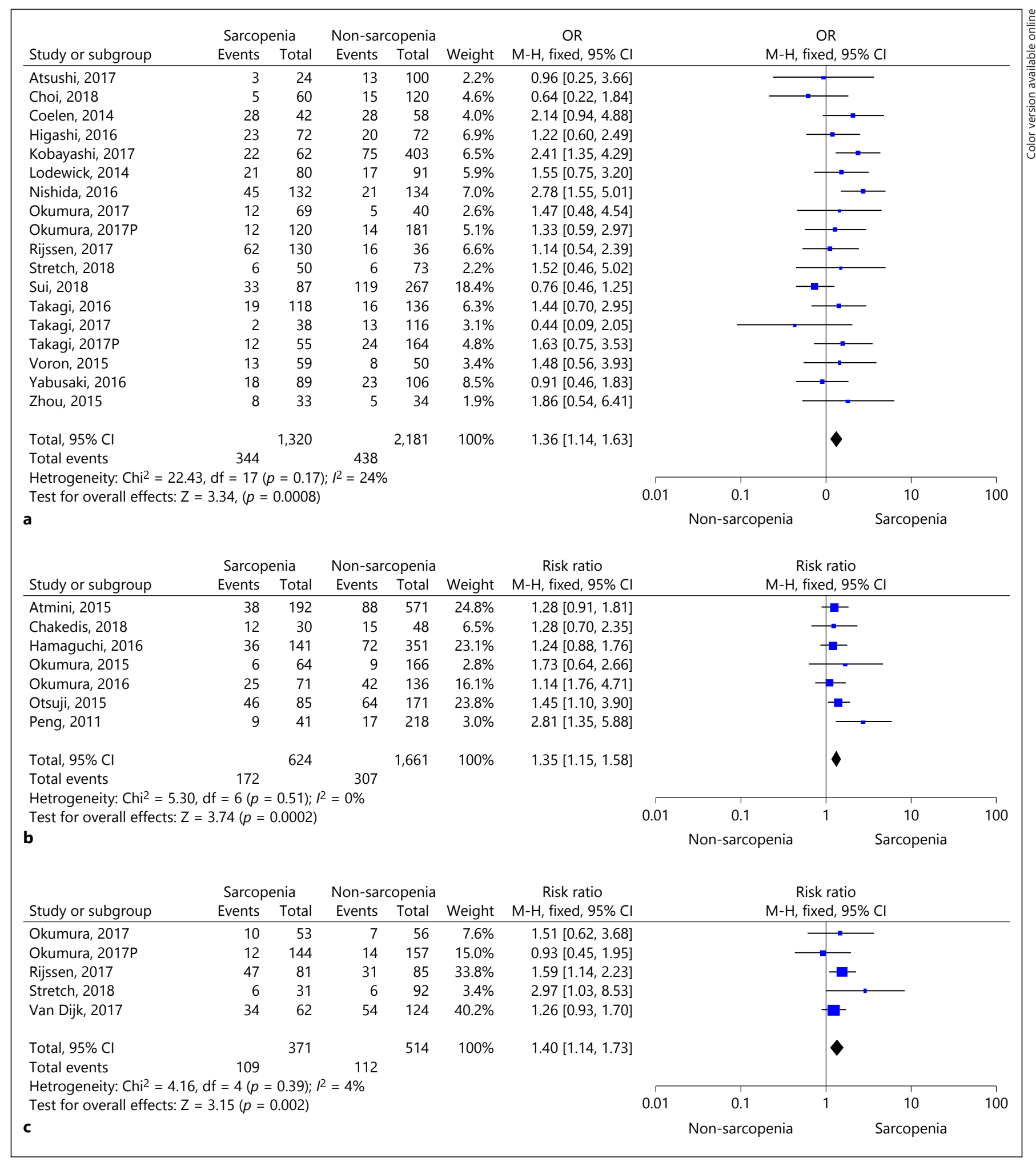

Fig. 2. a Forest plot comparing major complications in patients with low SMI versus patients with normal SMI. b Forest plot comparing major complications in patients with low PMI versus patients with normal PMI. c Forest plot comparing major complica- tions in patients with low MA versus patients with normal MA. d Forest plot comparing major complications in patients with high IMAC versus patients with normal IMAC.

(For figure 1d see next page.) 


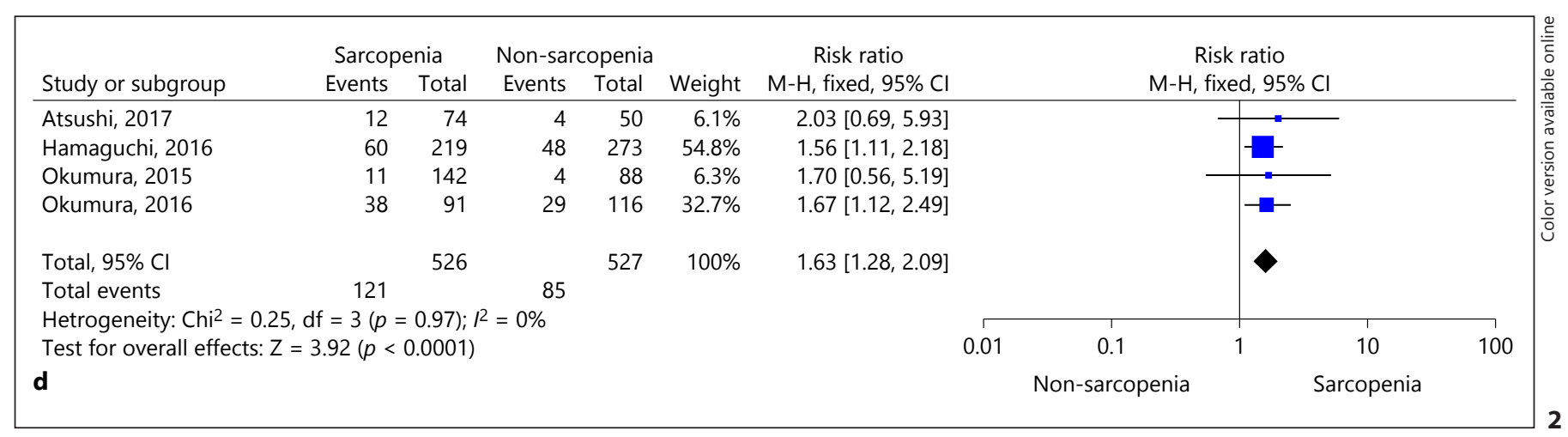

strength, and physical performance. It can be divided into 3 stages according to the severity of the condition. The "pre-sarcopenia" stage is characterized by the loss of muscle mass without any impact on muscle strength or physical performance. The "sarcopenia" stage is characterized by low muscle mass, plus low muscle strength or low physical performance. "Severe sarcopenia" is the stage identified when all 3 criteria of the definition are met [9]. The complexity of contents directly leads to the diversification of the methods to define sarcopenia. Dual X-ray absorptiometry, bio-electric impedance analysis, and CT can all be employed to measure muscle mass [9]. Even when only CT was employed, various indexes were used to define sarcopenia in different studies. According to these studies, CT-assessed sarcopenia indexes could be classified into 2 groups - SMI and PMI. While both SMI and PMI presented only the muscle quantity [19-20], MA, IMAC, HUAC, and LPMA were related to muscle quality [13, 14, 27, 35].

Among the muscle quantity indexes, SMI [19] calculated all the skeletal muscle mass, which included bilateral rectus abdominis, external oblique, internal oblique, transverse abdominal, psoas, and paraspinal muscles. However, PMI [20] calculated only the muscle mass of psoas. Apparently, measuring the psoas muscle area alone is much easier and less time-consuming; however, it is still unknown whether the psoas muscle alone adequately represents the muscle condition of the whole body. Rutten et al. [55] found a weak correlation between PMI and SMI in the assessment of sarcopenia in ovarian cancer, pointing out that psoas muscle was prone to be focally affected by degenerative diseases of the lumbar spine and this affection might be confused the muscle atrophy caused by cancer. Baracos [56] also indicated that psoas muscle alone does not reveal the muscle condition of the whole body. The characteristic of PMI as a reflection of the skeletal muscle condition of the whole body may need

CT-Assessed Sarcopenia Indexes Predict Major Complications further discussion. Indeed PMI was reported to be an effective predictor of major postoperative complications in many clinical studies [57-59] and our meta-analysis has also validated this role.

Among the muscle quality indexes, MA [13] represents the mean CT value of all the skeletal muscles in a targeted cross-sectional section and IMAC [20] is calculated by dividing the CT value of the multifidus muscles by the CT value of subcutaneous fat. Both HUAC [35] and LPMA [14] reveal both the muscle mass and the CT value of the bilateral psoas muscles, although the formulae for calculating these indexes vary. In previous studies $[60,61]$, sarcopenia was mainly defined by the skeletal muscle mass, and it was considered that muscle strength and physical performance were directly related to the muscle mass. However, it has now been noted that patients with adequate muscle mass might have a decreased level of muscle function and physical performance [37]. Therefore, numerous clinical researches have started to employ muscle quality to define sarcopenia. As CT-assessed muscle quality indexes, MA and IMAC have been confirmed to be valid predictors of major complications and survival in many studies $[62,63]$, and these conclusions were consistent with the outcomes of this metaanalysis. Owning to the scarcity of original publication, the overall effect of HUAC and LPMA could not be pooled; however, the predictive value of these 2 indexes has also been confirmed in other studies $[64,65]$.

In many studies, it has been verified that CT-assessed sarcopenia indexes are associated with postoperative short- and long-term outcomes; however, a consensus on cutoffs for these indexes is still lacking. Among the studies included in this analysis, some studies defined the cutoff by directly adopting predefined cutoffs and some performed optimum stratification or receiver operating characteristic curve. This lack of consensus has directly hampered sarcopenia evaluation in clinical practice and 
academic communication, and more researches need to be performed to reach an agreement.

One point that deserves attention is that most of the $I^{2}$ values in this study were rather low, suggesting negligible heterogeneity, which further enhances the credibility of the outcome. In fact, the study designs of most of the included studies were similar owing to the nature of the prognosis analysis of sarcopenia, especially with respect to participants' selection and image analysis in the original studies. In the IMAC part (Fig. 2d), all of the included studies were retrospective cohort studies, all of the participants were Japanese and 3 studies used identical image-processing software. This uniformity in study designs might explain the rather small heterogeneity.

In summary, this meta-analysis showed that both CTassessed muscle quantity sarcopenia indexes, SMI and $\mathrm{PMI}$, and muscle quality indexes, MA and IMAC, were effective predictors of major postoperative complications in patients following hepatopancreatobiliary surgery, and that more studies are needed to confirm the effectiveness of HUAC and LPMA. Thus, sarcopenia should be included in the preoperative risk evaluation, and to achieve this goal, a consensus on the cutoffs for sarcopenia indexes should soon be established.

\section{Disclosure Statement}

The authors declare no conflicts of interest.

\section{Funding Source}

NSFC (Natural Science Foundation of China, U1403222). This meta-analysis has been registered in PROSPERO, and the registration number is CRD42018102226.

\section{References}

1 Ljungqvist O, Scott M, Fearon KC: Enhanced recovery after surgery: a review. JAMA Surg 2017;152:292-298.

2 Green D: Role of Multimodal Monitoring (MMM) in the Perioperative Period: Improving Outcomes in High Risk Surgical Patients $[\mathrm{M}] /$ Perioperative Medicine-Current Controversies. Cham, Springer, 2016, pp 271300.

3 Kehlet H, Jørgensen CC: Advancing surgical outcomes research and quality improvement within an enhanced recovery program framework. Ann Surg 2016;264:237-238.

4 Blake P, Patel N, Brown C, Blackshaw G, Powell AG, Wheat J, Beamish A, Lewis WG: Prognostic significance of body composition determined by bioelectrical impedance analysis (BIA) in upper gastrointestinal cancer surgery. Gastroenterology 2017;152: S1269.

5 Nakashima Y, Saeki H, Nakanishi R, Sugiyama M, Kurashige J, Oki E, Maehara Y: Assessment of sarcopenia as a predictor of poor outcomes after esophagectomy in elderly patients with esophageal cancer. Ann Surg 2017;267: 1100-1104.

6 Hirasawa Y, Nakashima J, Yunaiyama D, Sugihara T, Gondo T, Nakagami Y, Horiguchi Y, Ohno Y, Namiki K, Ohori M, Tokuuye K, Tachibana M: Sarcopenia as a novel preoperative prognostic predictor for survival in patients with bladder cancer undergoing radical cystectomy. Ann Surg Oncol 2016;23(suppl 5):10481054.

7 Gillen J, Mills KA, Dvorak J, Zheng B, Thai T, Salani R, Cosgrove CM, Davidson B, Thaker $\mathrm{PH}$, Moore KN: Imaging biomarkers of adiposity and sarcopenia as potential predictors for overall survival among patients with endometrial cancer treated with bevacizumab. Gynecol Oncol 2017;147:198-199.

8 Rosenberg IH: Summary comments: epidemiological and methodological problems in determining nutritional status of older persons. Am J Clin Nutr 1989;50:1231-1233.

9 Cruz-Jentoft AJ, Baeyens JP, Bauer JM, Boirie Y, Cederholm T, Landi F, Martin FC, Michel JP, Rolland Y, Schneider SM, Topinková E, Vandewoude M, Zamboni M; European Working Group on Sarcopenia in Older People: Sarcopenia: European consensus on definition and diagnosis: report of the European working group on sarcopenia in older people. Age Ageing 2010;39:412-423.

10 Cederholm T, Barazzoni R, Austin P, Ballmer P, Biolo G, Bischoff SC, Compher C, Correia I, Higashiguchi T, Holst M, Jensen GL, Malone A, Muscaritoli M, Nyulasi I, Pirlich M, Rothenberg E, Schindler K, Schneider SM, de van der Schueren MA, Sieber C, Valentini L, Yu JC, Van Gossum A, Singer P: ES$\mathrm{PEN}$ guidelines on definitions and terminology of clinical nutrition. Clin Nutr 2017;36: 49-64.

11 Kobayashi A, Kaido T, Hamaguchi Y, Okumura S, Shirai H, Kamo N, Yagi S, Taura K, Okajima $\mathrm{H}$, Uemoto S: Impact of sarcopenic obesity on outcomes in patients undergoing hepatectomy for hepatocellular carcinoma. Ann Surg 2017, DOI: $10.1097 /$ SLA. 0000000000002555 .

12 Amini N, Spolverato G, Gupta R, Margonis GA, Kim Y, Wagner D, Rezaee N, Weiss MJ, Wolfgang CL, Makary MM, Kamel IR, Pawlik TM: Impact total psoas volume on short- and long-term outcomes in patients undergoing curative resection for pancreatic adenocarci- noma: a new tool to assess sarcopenia. J Gastrointest Surg 2015;19:1593-1602.

13 Okumura S, Kaido T, Hamaguchi Y, Kobayashi A, Shirai H, Fujimoto Y, Iida T, Yagi S, Taura K, Hatano E, Okajima H, Uemoto S: Impact of skeletal muscle mass, muscle quality, and visceral adiposity on outcomes following resection of intrahepatic cholangiocarcinoma. Ann Surg Oncol 2017;24:1037-1045.

14 OnestiJK,WrightGP, KenningSE,TierneyMT, DavisAT, DohertyMG,ChungMH:Sarcopenia and survival in patients undergoing pancreatic resection. Pancreatology 2016;16:284-289.

15 Clavien PA, Barkun J, de Oliveira ML, Vauthey JN, Dindo D, Schulick RD, de Santibañes E, Pekolj J, Slankamenac K, Bassi C, Graf R, Vonlanthen R, Padbury R, Cameron JL, Makuuchi M: The Clavien-Dindo classification of surgical complications: five-year experience. Ann Surg 2009;250:187-196.

16 Wells GA, Shea B, O'Connell D, et al: The Newcastle-Ottawa Scale (NOS) for Assessing the Quality of Nonrandomized Studies in Meta-Analysis. Ottawa, The Ottawa Health Research Institute, 2011.

17 DerSimonian R, Laird N: Meta-analysis in clinical trials. Control Clin Trials 1986;7:177188.

18 Brockwell SE, Gordon IR: A comparison of statistical methods for meta-analysis. Stat Med 2001;20:825-840.

19 Coelen RJ, Wiggers JK, Nio CY, Besselink MG, Busch OR, Gouma DJ, van Gulik TM: Preoperative computed tomography assessment of skeletal muscle mass is valuable in predicting outcomes following hepatectomy for perihilar cholangiocarcinoma. HPB (Oxford) $2015 ; 17: 520-528$. 
20 Hamaguchi Y, Kaido T, Okumura S, Kobayashi A, Fujimoto Y, Ogawa K, Mori A, Hammad A, Hatano E, Uemoto S: Muscle steatosis is an independent predictor of postoperative complications in patients with hepatocellular carcinoma. World J Surg 2016;40: 1959-1968.

21 Higashi T, Hayashi H, Taki K, Sakamoto K, Kuroki H, Nitta H, Hashimoto D, Chikamoto A, Beppu T, Baba H: Sarcopenia, but not visceral fat amount, is a risk factor of postoperative complications after major hepatectomy. Int J Clin Oncol 2016;21:310-319.

22 Coelen RJ, van Gulik TM: Preoperative sarcopenia negatively impacts postoperative outcomes following major hepatectomy with extrahepatic bile duct resection. World J Surg 2015;39:2368-2369.

23 Takagi K, Yagi T, Yoshida R, Shinoura S, Umeda Y, Nobuoka D, Kuise T, Watanabe N, Fujiwara T: Sarcopenia and American society of anesthesiologists physical status in the assessment of outcomes of hepatocellular carcinoma patients undergoing hepatectomy. Acta Med Okayama 2016;70:363-370.

24 Voron T, Tselikas L, Pietrasz D, Pigneur F, Laurent A, Compagnon P, Salloum C, Luciani A, Azoulay D: Sarcopenia impacts on shortand long-term results of hepatectomy for hepatocellular carcinoma. Ann Surg 2015;261: 1173-1183.

25 Yabusaki N, Fujii T, Yamada S, Suzuki K, Sugimoto H, Kanda M, Nakayama G, Koike M, Fujiwara M, Kodera Y: Adverse impact of low skeletal muscle index on the prognosis of hepatocellular carcinoma after hepatic resection. Int J Surg 2016;30:136-142.

26 Zhou G, Bao H, Zeng Q, Hu W, Zhang Q: Sarcopenia as a prognostic factor in hepatolithiasis-associated intrahepatic cholangiocarcinoma patients following hepatectomy: a retrospective study. Int J Clin Exp Med 2015;8: 18245-18254.

27 Kobayashi A, Kaido T, Hamaguchi Y, Okumura S, Shirai H, Kamo N, Yagi S, Taura K, Okajima H, Uemoto S: Impact of visceral adiposity as well as sarcopenic factors on outcomes in patients undergoing liver resection for colorectal liver metastases. World J Surg 2018;42:1180-1191.

28 Lodewick TM, van Nijnatten TJ, van Dam RM, van Mierlo K, Dello SA, Neumann UP, Olde Damink SW, Dejong CH: Are sarcopenia, obesity and sarcopenic obesity predictive of outcome in patients with colorectal liver metastases? HPB (Oxford) 2015;17:438-446.

29 Peng PD, Van Vledder MG, Tsai S, de Jong MC, Makary M, Ng J, Edil BH, Wolfgang CL, Schulick RD, Choti MA, Kamel I, Pawlik TM: Sarcopenia negatively impacts short-term outcomes in patients undergoing hepatic resection for colorectal liver metastasis. HPB (Oxford) 2011;13:439-446

30 Chakedis J, Spolverato G, Beal EW, Woelfel I, Bagante F, Merath K, Sun SH, Chafitz A, Galo J, Dillhoff M, Cloyd J, Pawlik TM: Pre-operative sarcopenia identifies patients at risk for poor survival after resection of biliary tract cancers. J Gastrointest Surg 2018:1697-1708.

31 Okumura S, Kaido T, Hamaguchi Y, Fujimoto Y, Kobayashi A, Iida T, Yagi S, Taura K, Hatano E, Uemoto S: Impact of the preoperative quantity and quality of skeletal muscle on outcomes after resection of extrahepatic biliary malignancies. Surgery 2016;159:821-833.

32 Choi MH, Yoon SB, Lee K, Song M, Lee IS, Lee MA, Hong TH, Choi MG: Preoperative sarcopenia and post-operative accelerated muscle loss negatively impact survival after resection of pancreatic cancer. J Cachexia Sarcopenia Muscle 2018;9:326-334.

33 Okumura S, Kaido T, Hamaguchi Y, Fujimoto Y, Masui T, Mizumoto M, Hammad A, Mori A, Takaori K, Uemoto S: Impact of preoperative quality as well as quantity of skeletal muscle on survival after resection of pancreatic cancer. Surgery 2015;157:1088-1098.

34 Okumura S, Kaido T, Hamaguchi Y, Kobayashi A, Shirai H, Yao S, Yagi S, Kamo N, Hatano E, Okajima H, Takaori K, Uemoto S: Visceral adiposity and sarcopenic visceral obesity are associated with poor prognosis after resection of pancreatic cancer. Ann Surg Oncol 2017;24:3732-3740.

35 Wagner D, Marsoner K, Tomberger A, Haybaeck J, Haas J, Werkgartner G, Cerwenka $\mathrm{H}$, Bacher H, Mischinger HJ, Kornprat P: Low skeletal muscle mass outperforms the Charlson comorbidity index in risk prediction in patients undergoing pancreatic resections. Eur J Surg Oncol 2018;44:658-663.

36 Sui K, Okabayshi T, Iwata J, Morita S, Sumiyoshi T, Iiyama T, Shimada Y: Correlation between the skeletal muscle index and surgical outcomes of pancreaticoduodenectomy. Surg Today 2018;48:545-551.

37 Van Rijssen LB, van Huijgevoort NC, Coelen RJ, Tol JA, Haverkort EB, Nio CY, Busch OR, Besselink MG: Skeletal muscle quality is associated with worse survival after pancreatoduodenectomy for periampullary, nonpancreatic cancer. Ann Surg Oncol 2017;24:272-280.

38 Stretch C, Aubin JM, Mickiewicz B, Leugner D, Al-Manasra T, Tobola E, Salazar S, Sutherland FR, Ball CG, Dixon E, Vogel HJ, Damaraju S, Baracos VE, Bathe OF: Sarcopenia and myosteatosis are accompanied by distinct biological profiles in patients with pancreatic and periampullary adenocarcinomas. PLoS One 2018;13:e0196235.

39 Nishida Y, Kato Y, Kudo M, Aizawa H, Okubo S, Takahashi D, Nakayama Y, Kitaguchi K, Gotohda N, Takahashi S, Konishi M: Preoperative sarcopenia strongly influences the risk of postoperative pancreatic fistula formation after pancreaticoduodenectomy. J Gastrointest Surg 2016;20:1586-1594.

40 Takagi K, Yoshida R, Yagi T, Umeda Y, Nobuoka D, Kuise T, Fujiwara T: Radiographic sarcopenia predicts postoperative infectious complications in patients undergoing pancreaticoduodenectomy. BMC Surg 2017;17:64.

41 van Dijk DP, Bakens MJ, Coolsen MM, Rensen SS, van Dam RM, Bours MJ, Weijen- berg MP, Dejong CH, Olde Damink SW: Low skeletal muscle radiation attenuation and visceral adiposity are associated with overall survival and surgical site infections in patients with pancreatic cancer. J Cachexia Sarcopenia Muscle 2017;8:317-326.

42 Takagi K, Yagi T, Yoshida R, Umeda Y, Nobuoka D, Kuise T, Fujiwara T: Sarcopenia predicts postoperative infection in patients undergoing hepato-biliary-pancreatic surgery. Int J Surg 2017;6:12-18.

43 Hamaguchi Y, Kaido T, Okumura S, Ito T, Fujimoto Y, Ogawa K, Mori A, Hammad A, Hatano E, Uemoto S: Preoperative intramuscular adipose tissue content is a novel prognostic predictor after hepatectomy for hepatocellular carcinoma. J Hepatobiliary Pancreat Sci 2015;22:475-485.

44 Hamaguchi Y, Kaido T, Okumura S, Kobayashi A, Shirai H, Yagi S, Kamo N, Okajima H, Uemoto S: Impact of skeletal muscle mass index, intramuscular adipose tissue content, and visceral to subcutaneous adipose tissue area ratio on early mortality of living donor liver transplantation. Transplantation 2017;101:565-574.

45 Fearon K, Strasser F, Anker SD, Bosaeus I, Bruera E, Fainsinger RL, Jatoi A, Loprinzi C, MacDonald N, Mantovani G, Davis M, Muscaritoli M, Ottery F, Radbruch L, Ravasco P, Walsh D, Wilcock A, Kaasa S, Baracos VE: Definition and classification of cancer cachexia: an international consensus. Lancet Oncol 2011;12:489-495.

46 Van Vledder MG, Levolger S, Ayez N, Verhoef C, Tran TC, Ijzermans JN: Body composition and outcome in patients undergoing resection of colorectal liver metastases. Br J Surg 2012;99:550-557.

47 Martin L, Birdsell L, MacDonald N, Reiman T, Clandinin MT, McCargar LJ, Murphy R, Ghosh S, Sawyer MB, Baracos VE: Cancer cachexia in the age of obesity: skeletal muscle depletion is a powerful prognostic factor, independent of body mass index. J Clin Oncol 2013;31:1539-1547.

48 Duceppe E, Lauzon JF, Gallinger S, Zhang B, Solomon H, Aybar PS: 956-Predictors of splanchnic vein thrombosis and mortality following hepatobiliary and pancreatic purgery. Gastroenterology 2018;154:S1296.

49 Bos S, Bernal W, Porte RJ, Lisman T: Hemostatic complications in hepatobiliary surgery. Semin Thromb Hemost 2017;43:732-741.

50 El Amrani M, Fulbert M, Lenne X, Clément G, Drumez E, Pruvot FR, Truant S: Do complications following pancreatic resections impact hospital costs in France: medico-economic study on 127 patients. J Visc Surg 2018;pii:S1878-7886(18)30055-9.

51 Van Vugt JLA, Buettner S, Levolger S, Coebergh van den Braak RRJ, Suker M, Gaspersz MP, de Bruin RWF, Verhoef C, van Eijck CHC, Bossche N, Groot Koerkamp B, IJzermans JNM: Low skeletal muscle mass is associated with increased hospital expenditure in patients undergoing cancer surgery of the alimentary tract. PLoS One 2017;12:e186547. 
52 Murimwa GZ, Venkat PS, Jin W, Leuthold S, Latifi K, Almhanna K, Pimiento JM, Fontaine JP, Hoffe SE, Frakes JM: Impact of sarcopenia on outcomes of locally advanced esophageal cancer patients treated with neoadjuvant chemoradiation followed by surgery. J Gastrointest Oncol 2017;8:808-815.

53 Kim EY, Lee HY, Kim KW, Lee JI, Kim YS, Choi WJ, Kim JH: Preoperative computed tomography-determined sarcopenia and postoperative outcome after surgery for nonsmall cell lung cancer. Scand J Surg 2018;107: 244-251.

54 van Vugt JLA, Alferink LJM, Buettner S, Gaspersz MP, Bot D, Darwish Murad S, Feshtali S, van Ooijen PMA, Polak WG, Porte RJ, van Hoek B, van den Berg AP, Metselaar HJ, IJzermans JNM: A model including sarcopenia surpasses the MELD score in predicting waiting list mortality in cirrhotic liver transplant candidates: a competing risk analysis in a national cohort. J Hepatol 2018;68:707-714.

55 Rutten IJG, Ubachs J, Kruitwagen RFPM, Beets-Tan RGH, Olde Damink SWM, Van Gorp T: Psoas muscle area is not representative of total skeletal muscle area in the assessment of sarcopenia in ovarian cancer. J Cachexia Sarcopenia Muscle 2017;8:630-638.

56 Baracos VE: Psoas as a sentinel muscle for sarcopenia: a flawed premise. J Cachexia Sarcopenia Muscle 2017;8:527-528.
57 Womer AL, Brady JT, Kalisz K, Patel ND, Paspulati RM, Reynolds HL, Pawlik TM, Steele SR: Do psoas muscle area and volume correlate with postoperative complications in patients undergoing rectal cancer resection? Am J Surg 2018;215:503-506.

58 Pedersen M, Cromwell J, Nau P: Sarcopenia is a predictor of surgical morbidity in inflammatory bowel disease. Inflamm Bowel Dis 2017;23:1867-1872.

59 Hawkins RB, Mehaffey JH, Charles EJ, Kern JA, Lim DS, Teman NR, Ailawadi G: Psoas muscle size predicts risk-adjusted outcomes after surgical aortic valve replacement. Ann Thorac Surg 2018;106:39-45.

60 Peng P, Hyder O, Firoozmand A, Kneuertz P, Schulick RD, Huang D, Makary M, Hirose K, Edil B, Choti MA, Herman J, Cameron JL, Wolfgang CL, Pawlik TM: Impact of sarcopenia on outcomes following resection of pancreatic adenocarcinoma. J Gastrointest Surg 2012;16:1478-1486.

61 Valero V, Amini N, Spolverato G, Weiss MJ Hirose K, Dagher NN, Wolfgang CL, Cameron AA, Philosophe B, Kamel IR, Pawlik TM: Sarcopenia adversely impacts postoperative complications following resection or transplantation in patients with primary liver tumors. J Gastrointest Surg 2015;19:272-281.
62 Kitajima Y, Hyogo H, Sumida Y, Eguchi Y, Ono N, Kuwashiro T, Tanaka K, Takahashi H, Mizuta T, Ozaki I, Eguchi T, Kimura Y, Fujimoto K, Anzai K; Japan Nonalcoholic Fatty Liver Disease Study Group (JSG-NAFLD): Severity of non-alcoholic steatohepatitis is associated with substitution of adipose tissue in skeletal muscle. J Gastroenterol Hepatol 2013; 28:1507-1514.

63 Fujiwara N, Nakagawa H, Kudo Y, Tateishi R, Taguri M, Watadani T, Nakagomi R, Kondo M, Nakatsuka T, Minami T, Sato M, Uchino K, Enooku K, Kondo Y, Asaoka Y, Tanaka Y, Ohtomo K, Shiina S, Koike K: Sarcopenia, intramuscular fat deposition, and visceral adiposity independently predict the outcomes of hepatocellular carcinoma. J Hepatol 2015;63: 131-140.

64 Joglekar S, Asghar A, Mott SL, Johnson BE Button AM, Clark E, Mezhir JJ: Sarcopenia is an independent predictor of complications following pancreatectomy for adenocarcinoma. J Surg Oncol 2015;111:771-775.

65 Miller BS, Ignatoski KM, Daignault S, Lindland C, Doherty M, Gauger PG, Hammer GD, Wang SC, Doherty GM; University of Michigan Analytical Morphomics Group: Worsening central sarcopenia and increasing intra-abdominal fat correlate with decreased survival in patients with adrenocortical carcinoma. World J Surg 2012;36:1509-1516. 